\title{
Pembuatan Tepung Singkong Termodifikasi Dengan Kapasitas 300.000 Ton/Tahun
}

\author{
Ilham Muttaqin Zarkasie, Wuwuh Wijang Prihandini, Setiyo Gunawan, Hakun Wirawasista A \\ Departemen Teknik Kimia, Fakultas Teknologi Industri, Institut Teknologi Sepuluh Nopember (ITS) \\ e-mail: gunawan@chem-eng.its.ac.id
}

\begin{abstract}
Abstrak-Dalam penelitian ini telah dilakukan perancangan pabrik Tepung singkong termodifikasi berbahan dasar singkong dengan kapasitas sebesar 300.000 Ton/tahun, waktu operasi 24 jam dan 300 hari/tahun. Tujuan perancangan pabrik Tepung singkong termodifikasi ini adalah untuk mensubstitusi kebutuhan tepung terigu Indonesia sehingga mampu menekan nilai impor tepung terigu. Pabrik Tepung singkong termodifikasi ini direncanakan akan didirikan di Kabupaten Wonogiri, Provinsi Jawa Tengah. Alasan pemilihan tempat ini adalah karena tersedianya sarana transportasi darat dan laut, ketersediaan listrik, air dan pemasaran produk dapat dilakukan di daerah sekitar pabrik dan luar pulau karena posisinya yang berada di tengah Indonesia. Proses yang digunakan dalam pabrik ini yaitu proses fermentasi dengan menggunakan bakteri Lactobacillus plantarum selama 5 hari untuk meningkatkan kadar protein tepung sehingga dapat mensubstitusi kandungan nutrisi dari tepung terigu itu sendiri. Proses dalam pabrik ini terdiri dari 3 tahap utama yaitu tahap persiapan bahan baku, tahap fermentasi, dan tahap penepungan. Sumber dana investasi berasal dari modal sendiri sebesar $60 \%$ biaya investasi dan modal pinjaman sebesar $40 \%$ biaya investasi dengan bunga sebesar $10,5 \%$ per tahun. Dari analisa perhitungan ekonomi didapat hasil investasi Rp 473.098.662.000 dengan IRR 44\%, POT 2 tahun 3 bulan, dan BEP $17,82 \%$
\end{abstract}

Kata Kunci-Fermentasi, Lactobacillus plantarum, Tepung singkong termodifikasi, Pabrik, Singkong.

\section{PENDAHULUAN}

$\mathrm{S}_{\mathrm{m}}^{\mathrm{N}}$ INGKONG atau ubi kayu (Manihot esculenta Crantz) merupakan salah satu sumber karbohidrat lokal Indonesia yang menduduki urutan ketiga terbesar setelah padi dan jagung. Tanaman ini merupakan bahan baku yang paling potensial untuk diolah menjadi tepung. Singkong segar mempunyai komposisi kimiawi terdiri dari kadar air sekitar 60\%, pati 35\%, serat kasar 2,5\%, kadar protein 1\%, kadar lemak, 0,5\% dan kadar abu $1 \%$, karenanya merupakan sumber karbohidrat dan serat makanan, namun sedikit kandungan zat gizi seperti protein.

Singkong segar mengandung senyawa glokosida sianogenik dan bila terjadi proses oksidasi oleh enzim linamarase maka akan dihasilkan glukosa dan asam sianida (HCN) yang ditandai dengan bercak warna biru, akan menjadi toxin (racun) bila dikonsumsi pada kadar HCN lebih dari 50 ppm. Pengelompokan ubikayu berdasarkan kadar $\mathrm{HCN}$ menjadi 3 kelompok, yaitu [1] tidak boleh dikonsumsi bila kadar $\mathrm{HCN}$ lebih dari 100 ppm (rasa pahit), [2] dianjurkan tidak diko nsumsi bila kadar HCN 40 - 100 ppm (agak pahit) dan [3] boleh dikonsumsi kadar HCN kurang dari 40 ppm (tidak pahit).

Ada korelasi antara kadar HCN ubikayu segar dengan kandungan pati. Semakin tinggi kadar HCN semakin pahit dan kadar pati meningkat dan sebaliknya. Oleh karenanya, industri tapioka umumnya menggunakan varietas berkadar $\mathrm{HCN}$ tinggi (varietas pahit). Di samping itu, ubikayu segar mengandung senyawa polifenol dan bila terjadi oksidasi akan menyebabkan warna coklat (browning secara enzimatis) oleh enzim fenolase. (Badan Penelitan dan Perkembangan Pertanian)

Tepung tepung singkong termodifikasi adalah tepung singkong yang dibuat dengan menggunakan prinsip modifikasi sel singkong secara fermentasi. Tepung ini merupakan komoditas tepung cassava dengan teknik fermentasi sehingga produk yang dihasilkan memiliki karakteristik mirip seperti terigu, yaitu putih, lembut, dan tidak berbau singkong. Dengan karakterisrik yang mirip dengan terigu, tepung tepung singkong termodifikasi dapat menjadi komoditas subtitusi tepung terigu. Indonesia memiliki tingkat permintaan yang tinggi terhadap tepung terigu, baik oleh industri atau rumah tangga. Sedangkan kapasitas produksi tepung terigu di Indonesia masih rendah, tingginya permintaan tepung terigu menyebabkan harga tepung terigu menyebabkan harga tepung terigu yang tinggi. Produksi gandum nasional belum mampu memenuhi total permintaan dalam negeri sehingga dari tahun ke tahun terjadi peningkatan impor gandum.

\section{URAIAN PROSES}

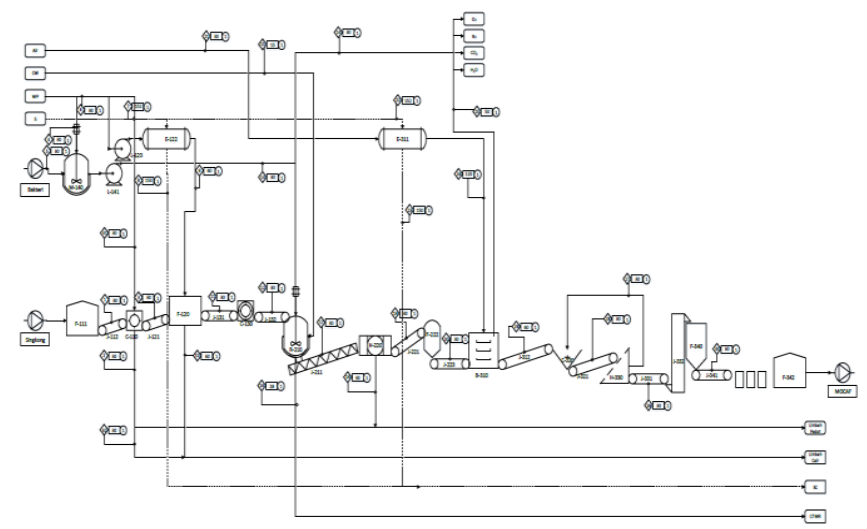

Gambar 1. Process Flow Diagram Pabrik Etilen Glikol

Teknologi pengolahan ubi kayu pada umumnya masih tradisional yaitu perebusan, penggorengan, pembuatan gaplek, 
penepungan (tepung kasava, tepung tiwul) dan ekstraksi pati tapioka. Salah satu usaha diversifikasi pengolahan ubi kayu yang saat ini sedang dikembangkan adalah tepung teplin\&3 singkong termodifikasi (modified cassava flour). Tepung tepung singkong termodifikasi adalah tepung ubi kayu yang dibuat dengan menggunakan prinsip modifikasi sel ubi kayu secara fermentasi. Proses fermentasi ubi kayu menghasilkan tepung dengan karakteristik berbau netral (cenderung harum), tekstur lembut, warna lebih putih. Selain itu, tepung ubi kayu yang difermentasi juga mempunyai kelebihan daripada tepung ubi kayu biasa, yaitu daya cerna, viskositas, kemampuan gelasi, daya rehidrasi dan kemudahan melarut, kemampuan mengikat air, HCN lebih rendah, aplikasi luas, dispersi ke produk pangan lebih mudah dan mudah membentuk 3 dimensi antar komponen sehingga konsistensi produk menjadi lebih baik. Teknologi proses pembuatan tepung ubi kayu fermentasi pertama kali diperkenalkan di Afrika Barat, terutama di Nigeria. Tepung yang dihasilkan digunakan sebagai makanan pokok dan dikenal dengan nama tepung gari.

Fermentasi adalah salah satu metode yang dapat mengurangi glukosida sianorganik pada singkong. Fermentasi juga menghasilkan senyawa volatil yang memberikan flavor unik pada produk. Proses fermentasi juga meningkatkan kadar protein, hal ini terlihat dari analisis proximat menunjukkan isi protein Lactobacillus plantarum dari fermentasi singkong menghasilkan protein tinggi, hal ini karena Lactobacillus plantarum mengeluarkan beberapa enzim ekstraseluler dengan produk lebih tinggi. Proses fermentasi juga meningkatkan kadar protein dari $1,5 \%$ hingga $8.58 \%$.

Proses fermentasi didefinisikan sebagai proses pembentukan alkohol atau asam laktat dari glukosa $\left(\mathrm{C}_{6} \mathrm{H}_{12} \mathrm{O}_{6}\right)$.

Glikolisis

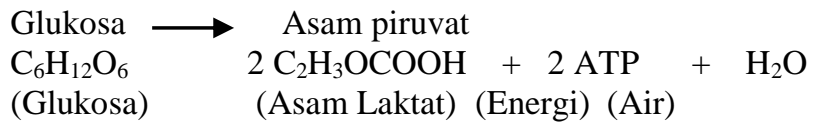

Fermentasi Alkohol :

$\mathrm{C}_{6} \mathrm{H}_{12} \mathrm{O}_{6} \longrightarrow \underset{\text { (Glukosa) }}{2 \mathrm{C}_{2} \mathrm{H}_{5} \mathrm{OH}} \underset{\text { (Alkohol) }}{+} \begin{aligned} & + \\ & \text { (Karbondioksida) }\end{aligned}$ (Energi)
$\mathrm{CO}_{2}+2 \mathrm{ATP}$

Proses pembuatan tepung singkong termodifikasi dengan proses fermentasi dibagi menjadi beberapa tahapan, yaitu:

1. Tahap persiapan bahan baku

2. Tahap pengolahan bahan baku

3. Tahap fermentasi

4. Tahap pengolahan produk

Singkong dari storage dikirim dengan menggunakan belt conveyor ke mesin pengupas kulit. Singkong yang sudah terpisah dari kulitnya di mesin pengupas kulit singkong kemudian dikirim ke mesin pencuci singkong untuk menghilangkan kotoran, lendir dan asam sianida pada singkong dengan menggunakan belt conveyor.

Selanjutnya dilakukan proses pencucian menggunakan air proses dengan suhu $30^{\circ} \mathrm{C}$ yang dipanaskan oleh heat exchanger sehingga suhu naik menjadi $60^{\circ} \mathrm{C}$. Singkong yang sudah dicuci bersih, dikirim melalui belt conveyor untuk dikecilkan ukurannya menggunakan mesin pemarut.

II.8.2 Setelah melalui proses pengecilan ukuran, kemudian parutan singkong dibawa dengan belt conveyor menuju tangki fermentor bersama dengan penambahan air proses, nutrient dan bakteri Lactobacillus plantarum yang telah dicampur di tangki pencampuran untuk selanjutnya memasuki tahap fermentasi.

Singkong difermentasikan dalam tangki fermentor. Dimana di dalam tangki penampung terdapat singkong yang berasal dari mesin parut dan campuran nutrient serta air proses yang dicampur pada tangki pencampur. Singkong yang telah diparut kemudian di fermentasi menggunakan Lactobacillus plantarum selama 3 hari atau 72 jam dengan suhu operasi $30^{\circ} \mathrm{C}$ dan dalam kondisi fermentasi anaerob.

Setelah melalui proses fermentasi di tangki fermentor, produk awal masih berupa singkong hasil fermentasi dalam bentuk slurry ke penampung sementara. Dari tangki penampung sementara kemudian dipisahkan antara padatan dan cairannya dengan menggunakan filter press atau rotary vacum filter, kemudian hasil pisahannya masih berupa slurry dimana yang berupa cairan masuk ke limbah cair sedangkan yang padat dengan bantuan belt conveyor masuk ke tangki penampung berikutnya.

Kemudian dari tangki penampung sementara dengan bantuan belt conveyor. Produk singkong dibawa menuju tray dryer untuk dikeringkan dan dikurangi kadar airnya hingga mencapai $12-14 \%$ dengan cara menggiling singkong sampai halus. Dalam proses pengeringan ini digunakan bantuan berupa udara yang diperoleh dari alam kemudian dipanaskan menggunakan heat exchanger sehingga menjadi udara panas dengan suhu 120 ${ }^{\circ} \mathrm{C}$, setelah proses pengeringan ini, dihasilkan produk tepung yang masih bertekstur kasar. Selanjutnya Tepung singkong termodifikasi diangkut menggunakan belt conveyor menuju ke proses penepungan.

Dari tray dryer, tepung singkong termodifikasi menuju crusher dengan menggunakan belt conveyor. Proses ini untuk mendapatkan tepung tepung singkong termodifikasi dengan ukuran yang lebih kecil, untuk memudahkan dalam proses pengayakan.

Dari crusher, tepung singkong termodifikasi diumpankan ke screener dengan menggunakan belt conveyor. Proses ini ditujukan untuk mendapatkan tepung tepung singkong termodifikasi dengan ukuran 80 mesh. Produk tepung singkong termodifikasi yang telah memenuhi ukuran diangkut menggunakan belt conveyor menuju bucket elevator kemudian diangkut menuju tempat penampungan sementara atau bin kemudian produk siap untuk di proses packaging di alat pengepakan. Sedangkan tepung singkong termodifikasi yang tidak lolos pengayakan, di recycle kembali ke crusher untuk dihancurkan kembali. Tepung tepung singkong termodifikasi dikemas dalam kemasan $1 \mathrm{~kg}$. Selanjutnya dikirim ke storage produk untuk selanjutnya dikirim ke konsumen.

\section{MATERIAL BALANCE}

Berdasarkan hasil perhitungan material balance pada pabrik Tepung singkong termodifikasi ini dibutuhkan bahan baku singkong sebanyak 1.745.254 ton/tahun, bakteri sebanyak 14.834 ton/tahun, dan air sebanyak 2.774 .385 ton/tahun untuk menghasilkan produk Tepung Tepung singkong termodifikasi sebanyak 300.000 ton/tahun. 


\section{ANALISA EKONOMI}

Dari hasil perhitungan neraca ekonomi, didapatkan Total Cost Investment untuk pabrik ini sebesar Rp 473.098.662.000, Internal Rate of Return sebesar $44 \%$, Break Event Point 17,82 $\%$, dan waktu pengembalian modal (Pay Out Time) selama 2 tahun 3 bulan. Pabrik beroperasi secara kontinyu selama 300 hari dan 24 jam.

\section{KESIMPULAN}

Hasil analisa perhitungan pada Pra Desain Pabrik Tepung Tepung singkong termodifikasi dengan proses fermentasi diperoleh beberapa kesimpulan antara lain :

- Dari segi teknis :

- Kapasitas rancangan pabrik tepung singkong termodifikasi direncanakan 300.000 ton/tahun.

- Lokasi pendirian pabrik adalah Kabupaten Wonogiri, Provinsi Jawa Tengah

- Bentuk hukum perusahaan yang direncanakan adalah Perseroan Terbatas (PT).

- Bentuk organisasi yang direncanakan adalah organisasi sistem garis dan staf dengan jumlah tenaga kerja yang dibutuhkan sebanyak 210 orang.
- Dari segi ekonomis :

- Modal investasi : Rp 473.098.662.000

- Biaya produksi per tahun : Rp 1.480.525.695.000

- Hasil jual produk per tahun : Rp 2.025.000.000.000

- Laba bersih per tahun $\quad:$ Rp 544.474 .305 .000

- Internal Rate of Return : $44 \%$

- Pay Out Time :2 tahun 3 bulan

- Break Even Point : $17,82 \%$

Dari hasil analisa baik aspek teknis dan ekonomis dapat disimpulkan bahwa pabrik Tepung singkong termodifikasi ini layak untuk didirikan.

\section{DAFTAR PUSTAKA}

[1] N. dkk Aida, "Pembuatan Tepung singkong termodifikasi (Modified Cassava Flour) Dengan Proses Fermentasi Menggunakan Rhizopus Oryzae Dan Saccharomyces Cerevisae," Institut Teknologi Sepuluh Nopember Surabaya, 2012.

[2] G. Akihandusi, A.A., Oboh, "Biochemical Changes In Cassava Products (Flour \& Gari) Subjected To Saccharomyces Cerevisae Solid Media Fermentation," Sci. Direct, 2002.

[3] F. dan W. H. S. Amanu, "Pembuatan Tepung Tepung singkong termodifikasi Di Madura (Kajian Varietas Dan Lokasi Penanaman) Terhadap Mutu Dan Rendemen," Universitas Brawijaya, 2014. 